INFO- 2255

UDK : 32:343.352

Primljeno / Received: 2021-10-11

Preliminary Communication

https://doi.org/10.32914/i.55.1-2.9

\title{
CURRENT STATE AND TRENDS IN THE DEVELOPMENT OF LEGISLATION TO PREVENT CORRUPTION
}

\author{
Bohdan M. Holovkin ${ }^{1}$, Mykola I. Melnyk2, Viktor M. Trepak ${ }^{3}$ \\ Department of Criminalistics, Yaroslav Mudryi National Law University, Kharkiv, Ukraine1; The Constitutional Court of \\ Ukraine, Kyiv, Ukraine; 'Department of Criminal Law and Criminology, Faculty of Law, Ivan Franko National University of \\ Lviv, Lviv, Ukraine ${ }^{3}$
}

\section{Abstract}

The purpose of the study is to provide theoretical and legal and comparative legal analysis of the essence, content, modern trends and features of anti-corruption legislation, develop proposals for improving Ukrainian anti-corruption legislation. In the process of solving research problems, general scientific methods of cognition were used, in particular: analysis, synthesis, comparison, analogy, deduction, induction, abstraction; as well as special methods: comparative legal, legal-sociological, formal-legal, systematic method and the method of structural-functional analysis etc. The analysis of criminal law norms shows that the main trends in the modernization of the criminal legislation of Ukraine on responsibility for crimes of corruption in general have a positive trend. At the same time, the criminal-legal impact on public relations associated with the commission of socially dangerous acts of a corrupt nature needs further improvement in order to prevent and timely suppress corruption crimes. In Ukraine, there are parallel systems of administrative and criminal liability for corruption-related offenses, which often leads to duplication and generally weakens the effectiveness of anti-corruption measures. In addition, the general anti-corruption laws adopted in Ukraine give the impression of a solid legal basis, but they are often inactive, since their provisions are not supported by sound law enforcement practice. Also, the anti-corruption experience of the proposed countries, such as Sweden, Finland, Germany and France really looks like a certain benchmark to which every country, including Ukraine, should strive and take example from them.

Keywords: corruption, anti-corruption legislation, anti-corruption policy, international anti-corruption treaties, EU integration.

\section{INTRODUCTION}

In the modern world, there is no state in which corruption is completely absent. Corruption as a negative phenomenon slows down the evolution of economic and legal systems, while preventing Ukraine from approaching the world's leading living standards /1/ (Baranetska, 2017). Among the negative consequences of corruption should be highlighted: the weakening of the economy, the undermining of public relations and trust between people. Corruption is the foundation of the prosperity of the shadow economy and tends to destroy the foundations of free enterprise on the principles of fair competition. Corruption is the key to unemployment, crimes and civil disorder. The corruption can weaken basic institutions and make obstacles for good governance. This phenomenon damages the rule of law, weakens state institutions and democracy, negatively affecting productivity and the economy/2/ (Razzante, 2019). 
Today, there is a tendency in the world to strengthen anti-corruption legislation. In the modern conditions, much attention is paid to anti-corruption policy and its legislative support, the introduction of new anti-corruption mechanisms, which will contribute to the successful implementation of anti-corruption strategy. In Ukraine, corruption has seeped into all spheres of public relations and has become one of the fundamental causes of the crisis of Ukrainian statehood. The defeat of most state institutions by the virus of corruption is the destruction of the socio-economic sphere, the degradation of law enforcement and the judiciary, the health care system, as well as domestic science and education /3/ (Bereza, 2014).

Over the last year, Ukraine's indicators in The Corruption Perceptions Index (CPI) /4/ (2020) have grown by 3 points. With 33 points out of 100 possible, Ukraine received 117th place out of 180 countries in the Corruption Perceptions Index list. According to the National Agency for the Prevention of Corruption survey on the level of corruption in Ukraine, corruption remains the second most important public problem, after the hostilities in Donetsk and Luhansk oblasts, which concern civil society, business and experts. At the same time, $46.3 \%$ of businesses are ready to choose a corrupt model of behavior /5/ (NAPC, 2020). More than $70 \%$ of Ukrainians are convinced that the level of corruption in the country has not decreased, and the government does not want to expose bribe-takers. According to Ukrainians, the largest number of bribe-takers is among civil servants (65\%), people's deputies $(64 \%)$, taxpayers $(62 \%)$, judges $(61 \%)$, and police $(54 \%)$. The last place in the ranking was occupied by representatives of religion (32\%) /6/ (Transpency International Ukraine, 2021).

Given that corruption is a significant obstacle to further democratic processes and the implementation of reforms identified as priorities for achieving economic prosperity, stability and sustainable development of our state, the political establishment, it is worth focusing on consistent, planned and coordinated action against corruption. At the same time, as world experience shows, no steps to combat corruption will be effective without political will at all levels of government /7/ (Rostovska, 2017). That is why the creation of an effective system for preventing corruption, development and implementation of a set of organizational and legal measures to combat this phenomenon, identify and overcome its social preconditions and consequences should become one of the priorities of the state /8/ (Kostenko \& Busol, 2016).

Anti-corruption issues constantly attract the attention of the scientific community both in Ukraine and abroad. It should be noted that this phenomenon is being studied in various aspects, in particular, for example, international legal aspect, socio-legal aspect, administrative-legal aspect, etc. In our study, we focus on the study of corruption in the criminal-legal aspect. The theoretical basis of the study are scientific papers on criminal law and criminology, as well as international law, philosophy, economics, political science, sociology, etc.

T. Khabarova /9/ researched foreign experience in preventing corruption. A. Brovyk /10/ analyzed the genesis of criminal liability and prevention of corruption crimes in Ukraine. O. Bereza /11/ studied corruption in public administration as a deterrent to socio-economic reforms. O. Kostenko and O. Busol /12/ explored new approaches to the concept of combating corruption crime in Ukraine. K. Rostovska /13/ analyzed the international experience of forming and implementing anti-corruption policy in foreign countries. A number of foreign scholars have also addressed issues related to the development of anti-corruption legislation. For example, L. Chuah, N. Loayza, and B. Myers /14/ concluded that the reforms to fight corruption should include streamline rules and regulations; build a meritocratic and well-paid civil service; promote transparency in public employment, procurement, and services; enable citizen voice and government accountability; enforce anti-corruption laws and penalties. 
I. Brusca, M. Rossi and N. Aversano /15/ analyzed whether transparency, the quality of budgetary management and the strength of audit institutions have a positive effect on corruption and can increase trust in governments from a comparative analysis. At the same time, it should be noted that today there is still no holistic systemic study of this topic. In particular, there are insufficiently studied issues related to the definition of the essence of corruption, analysis of the causes and prerequisites for its existence, various aspects of its occurrence, etc. A number of key issues in preventing, combating and investigating corruption are poorly understood in scientific terms. This primarily concerns the understanding of the legal nature of corruption, defining its nature, scope, subjects, types of corruption offenses, corruption crime, mechanism and factors of corruption, trends in its development, the content of anti-corruption activities, its subjects, directions, etc.

\section{MATERIALS AND METHODS}

The article was performed using philosophical, general scientific and special methods, which were selected taking into account the purpose of the study. Inter alia, in the process of solving research problems, general scientific methods of cognition were used, in particular: analysis, synthesis, comparison, analogy, deduction, induction, abstraction; as well as special methods: comparative legal, legal-sociological, formal-legal, etc. The methodological basis of the study was formed by the principles of theoretical and legal analysis used in the process of studying the essence, content and features of the formation of the Ukrainian legal order in the field of combating corruption, identifying contradictions in the functioning and development of proposals for its improvement. It should be also noted that the dialectical method played a fundamental role in the study, in particular, it revealed trends in anti-corruption legislation.

In addition, in the article the dialectical method allowed to consider the objective legal phenomena of anti-corruption as those that are interrelated with social, economic and political processes, etc. Also, the article carried out the analysis and synthesis of not only theoretical, but also legal, in particular, forensic research. The synergetic method allowed to substantiate the trends of anti-corruption legislation in Ukraine.The systematic method and the method of structural-functional analysis allowed to study the provisions of international anti-corruption acts, the current Criminal Code of Ukraine in terms of liability for corruption crimes and the practice of its application in their relationship and connect them with scientific ideas about criminal law against corruption. A special place in the methodological basis of this article is carried out by the methods of comparative theoretical analysis.

In particular, the comparative legal method was used to identify the peculiarities of the legislation of different countries on the successful fight against corruption. The application of the historical method of research of legal phenomena allowed to reveal the genesis of the anti-corruption legislation of Ukraine. The method of legal hermeneutics was used to understand, interpret and apply the meaning of the legal text, as well as to determine the methods of its formulation and perception. It should be noted, that the other scientific methods were also used in their relationship, which, together with the above, helped to ensure the comprehensiveness, completeness and objectivity of the study and the truth of the results. The normative basis of the dissertation is the Constitution of Ukraine, international legal acts in the field of anti-corruption, the Criminal Code of Ukraine, acts of anti-corruption legislation of Ukraine and the legislation of some foreign countries, and others. The theoretical basis of the research is formed by scientific works on criminal law, international law and other branches of science.

\section{RESULTS}

Corruption has emerged in society since the inception of the state, it actually originated with the state apparatus, the emergence of managers who quickly saw the opportunity to use state power for personal gain. Corruption is a major threat to national security, as it undermines the financial 
system, public confidence in the state, and the ability of civil servants to protect national interests through the use of office for their own enrichment. Information about the corruption of that time is considered in the works of the ancient Greek philosophers Plato and Aristotle, who repeatedly mentioned the destructive effects of abuse of power and bribery on the economic, political and spiritual life of society.

At the end of the 21st century, corruption has become global and has become a significant obstacle to the development of international relations. Ukraine, which has long been among the countries with a high level of corruption, is no exception. The concept of corruption in the conventional sense of the phenomenon was first formulated by the 34th Session of the United Nation General Assembly in 1979. The experts of this organization defined corruption as the performance by officials of any actions or inaction in the exercise of their official powers for remuneration in any form. who provides this remuneration, both in violation of job descriptions and without their violation.

The corruption in Ukraine today has features that distinguish it from this phenomenon in other countries. Without identifying these features, it is impossible to develop adequate measures to combat it /16/. Corruption in Ukraine belongs to the crisis type. This type has the following features:

1) it is caused by the crisis of modern Ukrainian society, and not only by the imperfection of criminal justice;

2) is able to deepen the crisis of Ukrainian society, nullifying any political, economic, legal, moral reforms in Ukraine. This is a threat to Ukraine's national security.

It should be noted that Ukraine has signed a number of important international anti-corruption agreements, including The United Nation Convention against Corruption /17/, The OECD Conventions on Combating Bribery of Foreign Public Officials in International Business Transactions
/18/, The Civil Convention against Corruption /19/, The Criminal Convention for the Suppression of Corruption $/ \mathbf{2 0} /$, The Additional Protocol to the Criminal Convention on Corruption fight against corruption $/ \mathbf{2 1} /$, etc. In addition, Ukraine joined the Istanbul Anti-Corruption Action Plan /22/. It should be noted that despite the fact that international standards require the criminalization of corruption, Ukraine has parallel systems of administrative and criminal liability for corruption-related offenses, which often leads to duplication and generally weakens the effectiveness of anti-corruption measures. In addition, the general anti-corruption laws adopted in Ukraine give the impression of a solid legal basis, but they are often inactive, since their provisions are not supported by sound law enforcement practice.

Under the influence of European integration processes, Ukrainian anti-corruption legislation has undergone significant changes. In particular, 2013 was a landmark year in bringing the domestic anti-corruption legislation to international standards. The Verkhovna Rada of Ukraine adopted a package of anti-corruption laws, such as the Law of Ukraine "On Principles of Preventing and Combating Corruption" /23/, the Law of Ukraine "On Amendments to Certain Legislative Acts on Liability for Corruption Offenses" /24/, etc. A number of anti-corruption laws were also adopted in 2014, inter alia: Principles of State Anti-Corruption Policy in Ukraine (Anti-Corruption Strategy) for 2014-2017 /25/, Law of Ukraine "On Prevention of Corruption" /26/, Law of Ukraine "On the National Anti-Corruption Bureau" /27/.

At the same time, taking into account the European integration aspirations of Ukraine, it is necessary to analyze in more detail the legislation of the European Union regarding this issue.

Thus, in the European Union, Directive on the protection of whistleblowers /28/ entered into force and began to apply, which is aimed at creating in national legislation a system of legal protection for persons reporting facts, including corruption offenses, which they became aware of 
during their official activities. The Directive on the protection of whistleblowers provides for a very wide range of persons falling under its protection. These are, in particular, self-employed, volunteers and interns, shareholders and top management of corporate structures, employees, employees of counterparty organizations, contractors, subcontractors and suppliers, etc., as well as family members, business partners of such persons, since their rights may be violated due to the disclosure of information by the informant $/ 29 /$.

At the same time, the Directive on the protection of whistleblowers notes that its effect extends to cases of reporting corruption violations in the field of public procurement, money laundering and terrorist financing and other strategic areas that are important for the interests of the European Union. The Directive on the protection of whistleblowers provides for the main methods of reporting by the informant of the relevant information: through the internal channels of the organization, through external channels (reporting to law enforcement agencies) and disclosure of information through public channels through the media. The Directive on the protection of whistleblowers also defines the main areas that require consolidation in the national legislation of the European Union member states in the near future, including the creation of internal channels for reporting violations in large organizations, as well as special training for their employees, and providing informants with free legal assistance, if necessary.

In response to the adopted Directive on the protection of whistleblowers, amendments to the relevant Law of Ukraine "On the Prevention of Corruption" /30/ came into force in Ukraine. In particular, the Ukrainian legislator provides for three similar channels for presenting information about manifestations of corruption: internal channels, external channels and regular channels. It is also allowed to submit anonymous messages and it is mandatory to check the facts of corruption indicated in them. Thus, a whistleblower is an individual who reports on the facts of possible corruption offenses that have become known to him in the course of labor, professional, economic, social or scientific activities, during service or training, or during participation in procedures preceding the commencement of such activities, and believes that the information disclosed by him is reliable.

Also, the Law of Ukraine "On the Prevention of Corruption" introduced a mechanism of monetary remuneration for reporting the facts of corruption for applicants reporting a corruption crime if the illegal income received as a result of such a crime or damage to the state is five thousand or more times higher than the minimum wage labor in Ukraine. It should be also noted, that in Ukraine, there are parallel systems of administrative and criminal liability for corruptionrelated offenses, which often leads to duplication and generally weakens the effectiveness of anticorruption measures. The practice of application of the legislation in Ukraine has caused a problem of distinction of structure of the administrative offense provided by article 172-2 Code of Ukraine on Administrative Offenses /31/, and structure of the crime provided by article 368 by the Criminal code of Ukraine $/ 32 /$, as the dispositions of both articles, in essence, provide for liability for the receipt of a benefit or bribe for the performance or non-performance of actions using official position. That is why, taking into account international standards in this sphere, the corruption in Ukraine should be completely criminalized.

Approximation of Ukrainian legislation to the European standards determines the need to adopt foreign experience in combating and preventing corruption. First of all, it is necessary to give the deffinition of corruption, which is contained in the legislation of some European countries. In our research we will analyze the experience of Sweden, Finland, Germany and France (Table 1). 
Table 1: Foreign experience in combating and preventing corruption

\begin{tabular}{|l|l|l|}
\hline Country & Definition & Legislation \\
\hline Sweden & $\begin{array}{l}\text { An employee or person performing an assignment who, for himself } \\
\text { or another person, receives, accepts a promise of, or demands an im- } \\
\text { proper benefit for the performance of the employment or assignment, } \\
\text { may be deemed as taking a bribe. A person who gives, promises or } \\
\text { offers an improper benefit in cases referred to above may, on the } \\
\text { other hand, be viewed as giving a bribe. }\end{array}$ & $\begin{array}{l}\text { Swedish Penal } \\
\text { Code }\end{array}$ \\
\hline Finland & $\begin{array}{l}\text { Finland's Criminal Code prohibits active and passive brib- } \\
\text { ery, embezzlement, fraud, abuse of office, breach of trust and abuse } \\
\text { of insider information. It criminalizes bribery between businesses, the } \\
\text { bribery of Finnish and foreign public officials, and bribery through } \\
\text { intermediaries (agents, consultants or other representatives). }\end{array}$ & $\begin{array}{l}\text { Finland Criminal } \\
\text { Code }\end{array}$ \\
\hline Germany & $\begin{array}{l}\text { Most of the German anti-bribery and corruption provisions are laid } \\
\text { down in Sections 331-338 (bribery in public office), 299-302 (bribery in } \\
\text { commercial business transactions) and 108b-198e (electoral bribery) of } \\
\text { the German Criminal Code }\end{array}$ & $\begin{array}{l}\text { German Criminal } \\
\text { Code }\end{array}$ \\
\hline France & $\begin{array}{l}\text { Bribery of French public officials is regulated under the French Crimi- } \\
\text { nal Code, Articles 433-1, 1 (active bribery, i.e., committed by the per- } \\
\text { son bribing a public official) and 432-11, 1 (passive bribery, i.e., com- } \\
\text { mitted by the public official who is bribed). }\end{array}$ & $\begin{array}{l}\text { French Criminal } \\
\text { Code }\end{array}$ \\
\hline
\end{tabular}

The study of effective elements of the anti-corruption system in foreign countries has always been an effective method in reforming anti-corruption legislation, inter alia, Ukrainian one. For example, in Sweden, a set of measures to combat corruption was approved in the nineteenth century, making it the initiator of this issue. An important emphasis was placed on the formation of moral and ethical norms for officials, which at that time minimized cases of bribery /33/. This was facilitated by the creation of an independent judiciary, as well as the exclusive rights of the state and the initiated transparency of public administration. An important role was played by public opinion, which strongly condemned all those who committed corruption, even forcing them to resign. Sometimes it was about those who are only suspected of corruption. After many years of reform, Sweden has an exemplary reputation as the country with the lowest level of corruption /34/.

The Finnish legal system is not characterized by laws using the term "fighting" to define a particular type of crime. The Finnish legislator has laid down the principles of prevention of crimes in each legal act, which define a specific area of activity, not the type of crime. There is no concept of "corruption" in the Finnish Criminal Code, only mentioning bribery of officials, which is punishable by a fine to imprisonment for up to 4 years, depending on the seriousness of the offense. Finland has never had a special law on corruption. It is considered part of a criminal offense and is always subject to the Constitution, the Criminal Code, the Civil Service Law, and administrative instructions /35/. The low level of corruption in Finland is also due to the main lever - honest government, which directs its activities to interact with civil society, as well as the traditions and values of the nation. Honest power does not depend on personalities, it is embedded in the culture and mentality of the people. Every official who holds a position in a public authority is obliged to serve it $/ \mathbf{3 6} /$.

French law provides for sanctions for bribery, which means the unlawful receipt, extortion of gifts, promises or any other advantage for the 
commission of acts within the authority of an official. French law is also known for such an offense as trading in influence - abuse of office by a public and private person in order to obtain a position from the government or another decision favorable to the bribe-giver $/ 37 /$.

The anti-corruption struggle in Germany is based on the task of destroying the material, primarily financial, base of anti-legal groups. There are two ways to do this: confiscation (confiscation of property) and creating a proper legal environment where it is impossible to launder "dirty" money. Among the anti-corruption mechanisms used by Germany from foreign experience is also a plan to create a register of corrupt companies. The point is that an enterprise that is included in such a register no longer has the right to fulfill any government orders and is more closely monitored by law enforcement agencies /38/.

The analysis of theory, practice and normative legal acts gives a general idea of the anti-corruption system in Germany, which is based on the following principles: protection of the state treasury and competition through the corruption register; creating incentives for a new business ethic; prohibition of officials dismissed from service for providing patronage from being involved in entrepreneurship for five years; closing gaps in laws; authorized control over telephone conversations; settlement of the position of the main witness by means of mitigation of punishment; strengthening criminal prosecution through the creation of anti-corruption centers; ensuring broad publicity of its activities; creation of helplines; strengthening control in order to prevent self-enrichment and abuse of subjective rights. To conclude, it should be noted, that to reduce the level of corruption, it is necessary to form anti-corruption legal awareness of citizens through the introduction of social and educational programs, the creation of a system of anti-corruption education.

\section{DISCUSSION}

The issue of the development of legislation to prevent corruption was anilized in recearch papers of some scientiests. For example, A. Brovyk /39/ identified six main periods of genesis of criminal responsibility and prevention of corruption crimes in the lands and territories that were part of modern Ukraine:

1) limited corruption practices during the existence of the Kyiv state and lands formed after the feudal collapse (XI-XIII centuries);

2) corrupt practices of "feeding" and the establishment of the first prohibitions of corruption (XIII century - 1555);

3) clarification and specification of corpus delicti and the development of principles for their prevention (mid-sixteenth century - 1845);

4) the formation of an established system of combating corruption (1845-1921);

5) the Soviet period of criminalization and prevention of corruption (1921 - early 90s of the XX century);

6) the modern period of criminal responsibility and prevention of corruption crimes and corruption offenses (early 90's of the XX century and to the present).

In turn, V. Vasylevych /40/ rightly notes that currently the state's attempts to overcome corruption have not achieved the desired results. Therefore, for real anti-corruption changes in Ukraine it is necessary to take the following steps: to ensure the proper functioning of independent anti-corruption bodies, in particular to implement the National Agency for Prevention of Corruption, providing adequate funding for this body, initiating the electronic declaration system, and ensuring transparent operation The National Anti-Corruption Bureau and the Specialized Anti-Corruption Prosecutor's Office; implement the law on transparent financing of political parties; carry out real judicial reform; to end the judicial practice of releasing high-ranking bribe-takers from imprisonment; to ensure the principle of inevitable punishment for officials who have committed 
a corruption crime, in particular for submitting false information in the declaration; implement the law on public procurement; reduce corruption risks during public procurement.

O. Dudorov /41/ believes that there are grounds to criticize the anti-corruption legislation of Ukraine for its instability, complexity, excessive detail of the description of certain torts, and so on. However, it is clear that even high-quality legislation does not guarantee fair and balanced law enforcement. A. Subbot and Y. Demyanchuk /42/ note that the fight against corruption should not only be systematic and directed against certain representatives of the top bureaucracy, but also against third parties who participated in illicit enrichment schemes, including representatives of commercial structures. In our study, we focused on current trends in anti-corruption legislation. The anti-corruption legislation of Ukraine is constantly being improved, becoming more holistic and systemic. Today, combating corruption is considered one of the main functions of the state.

Considering that the European integration vector for Ukraine is not only a priority, but also a promising one, in order to improve cooperation and relations between Ukraine and the European Union, the main step in this context should be the development of the successful anti-corruption legislation in the country /43/. That is why in this study the main emphasis was made on the analysis of the latest legislation of the European Union and its implementation in the Ukrainian legal system. It should be also noted, that despite the strengthening in modern conditions of exchange of experience in the field of fighting corruption between countries, almost every state in the world counteracts this problem with a certain specificity.

In one case, as in Finland and Sweden, an intolerant attitude towards it has been formed in society, which, together with various non-state movements that foster such rejection among the population, allows countries to remain in leading positions with a minimum corruption perception index. In the other, leadership is associated with active rule-making and consistent enforcement. Germany is also an example of a European country with significant achievements in the fight against corruption. German civil servants are exemplary of honesty, integrity and dedication to their cause.

\section{CONCLUSION}

The analysis of criminal law norms shows that the main trends in the modernization of the criminal legislation of Ukraine on responsibility for crimes of corruption in general have a positive trend. At the same time, Ukrainian legislation in the field of preventing and combating corruption is currently being reformed. The criminal-legal impact on public relations associated with the commission of socially dangerous acts of a corrupt nature needs further improvement in order to prevent and timely suppress corruption crimes. In Ukraine, there are parallel systems of administrative and criminal liability for corruption-related offenses, which often leads to duplication and generally weakens the effectiveness of anti-corruption measures. In addition, the general anticorruption laws adopted in Ukraine give the impression of a solid legal basis, but they are often inactive, since their provisions are not supported by sound law enforcement practice.

Summing up, it should be noted, that the anti-corruption experience of the proposed countries, such as Sweden, Finland, Germany and France really looks like a certain benchmark to which every country, including Ukraine, should strive. Their main advantage is good governance, as public administration bodies, in exercising their powers, are aware of the importance of their actions for the well-being of society, assess management activities as prestigious and value their reputation. In addition, in Finland and Sweden, an intolerant attitude towards it has been formed in society, that allows countries to remain in leading positions with a minimum corruption perception index. Germany and France are also examples of European countries with significant achievements in the fight against corruption. That is why, to reduce the level of corruption, it is necessary to form anti-corruption legal awareness of citizens 
through the introduction of social and educational programs, the creation of a system of anticorruption education.

At the same time, simple copying of foreign anticorruption methods and techniques without taking into account mentality is not a good way to improove the legislation. The most difficult thing is to change the habits of society and direct its activities into the area of control. Although it is society that is the strictest and most effective controller for any official. Taking into account all about mentioned, it could be proposed the following ideas to improve the results of anti-corruption reforms:

1) It is necessary to develop a detailed legislative framework that provides for strict restrictions on ethical standards, norms for cooperation between public and private structures, control over the distribution of government orders and tenders, criminal liability for malfeasance, up to the confiscation of property of officials and their families.

2) It is important, following the example of foreign countries, to reduce the state apparatus to the required minimum, to introduce personal responsibility and strict job descriptions.

3) To conclude, it should be noted, that combating corruption is a large-scale national task, and without a serious political will of the state, without organizing purposeful, systematic work to eradicate it and minimize its negative consequences, without joint actions in this direction by the authorities and civil society institutions, achieve effective results in solving this problem is impossible.

Notes

/1/ Baranetska, O. (2017), Anti-corruption in Ukraine: analysis of the situation and legislative support. Relevant Problems of Jurisprudence, 9, 81-86.

/2/ Razzante, R. (2019), The Fight Against Corruption. Retrieved from https://www.adrioninterreg.eu/wpcontent/uploads/2019/11/The-Fight-Against-Corruption.pdf
/3/ Bereza, O. (2014), Corruption in the field of public administration as a deterrent to socio-economic reforms. Public Administration: Theory and Practice,1, 173-180.

/4/ Transparency International. (2020), The Corruption Perceptions Index (CPI). Retrieved from https://images.transparencycdn.org/images/CPI2020_Report_EN_0802-WEB-1_2021-0208-103053.pdf

15/ NAPC. (2020), Corruption in Ukraine 2020: understanding, perception, prevalence. Retrieved from https://nazk.gov.ua/wpcontent/uploads/2020/05/Corruption_Survey_2020 _Presentation_Info-Sapiens.pdf

/6/ Transpency International Ukraine. (2021), Ukrainians are extremely dissatisfied with the level of the fight against corruption. Retrieved from http://tiukraine.org/news/media-about-us/6477.html

/7/ Rostovska, K. (2017), International experience in the formation and implementation of anti-corruption policy in other countries. Relevant Problems of Jurisprudence, 4, 118-122.

/8/ Kostenko, O., \& Busol, O. (2016), The concept of combating corruption crime in Ukraine needs new approaches: basic theses. Public Law, 2, 208-217.

19/ Khabarova, T. (2019), Foreign experience in preventing corruption. The Journal of V.N. Karazin Kharkiv National University, 2, 71-77.

/10/ Brovyk, A. (2019), Genesis of criminal liability and prevention of corruption crimes in Ukraine. Relevant Problems of Domestic Jurisprudence, 6, 118124.

/11/ op. sit. in /3/

/12/ op. sit. in /8/

/13/ op. sit. in /7/

/14/ Chuah, L., Loayza, N., \& Myers, B. (2020), The fight against corruption: taming tigers and swatting flies. Research \& Policy Briefs from the World Bank Malaysia Hub, 27, 1-4.

/15/ Brusca, I., Rossi M., \& Aversano N. (2018), Accountability and transparency to fight against corruption: an international comparative analysis. Journal of Comparative Policy Analysis: Research and Practice, 5, 486-504.

/16/ Ovcharenko, M.O., Tavolzhanskyi, O.V., Radchenko, T.M., Kulyk, K.D., \& Smetanina, N.V. (2020), Combating illegal drugs trafficking using the internet by means of the profiling method. Journal of Advanced Research in Law and Economics, 11(4), 1296-1304.

/17/ The United Nation Convention against Corruption. (2003), Retrieved from https://zakon.rada.gov.ua/laws/show/995_c16\#Text 
/18/ The OECD Conventions on Combating Bribery of Foreign Public Officials in International Business Transactions. (1997), Retrieved from https://zakon.rada.gov.ua/laws/show/995_c16\#Text

/19/ The Civil Convention against Corruption. (1999), Retrieved from https://zakon.rada.gov.ua/laws/show/994_102\#Text

/20/ The Criminal Convention for the Suppression of Corruption. (1999), Retrieved from https://zakon.rada.gov.ua/laws/show/994_101\#T ext

/21/ The Additional Protocol to the Criminal Convention on Corruption fight against corruption. (2003), Retrieved from https://zakon.rada.gov.ua/laws/show/994_172\# Text

/22/ Istanbul Anti-Corruption Action Plan. (2003), Retrieved from https://zakon.rada.gov.ua/laws/show/966_00104\#Text

23/ Verkhovna Rada of Ukraine. (2014), Law of Ukraine "On Principles of Preventing and Combating Corruption". Retrieved from https://zakon.rada.gov.ua/laws/show/170018\#Text

/24/ Verkhovna Rada of Ukraine. (2011), Law of Ukraine “On Amendments to Certain Legislative Acts on Liability for Corruption Offenses". Retrieved from https://zakon.rada.gov.ua/laws/show/3207-17\#Text

/25/ Principles of State Anti-Corruption Policy in Ukraine (Anti-Corruption Strategy) for 20142017. (2014). Retrieved from https://zakon.rada.gov.ua/laws/show/1699$18 \#$ Text

/26/ Verkhovna Rada of Ukraine. (2014), Law of Ukraine "On Prevention of Corruption". Retrieved from https://zakon.rada.gov.ua/laws/show/170018\#Text

/27/ Verkhovna Rada of Ukraine. (2014), Law of Ukraine "On the National Anti-Corruption Bureau". Retrieved from https://zakon.rada.gov.ua/laws/show/1698$18 \#$ Text

/28/ Directive on the protection of whistleblowers. (2019), Retrieved from https:/eurlex.europa.eu/legalcontent/EN/TXT/?uri=CELEX\%3A32019L1937\&q $\mathrm{id}=1621602664091$

/29/ Vapniarchuk, V.V., Puchkovska, I.I., Tavolzhanskyi, O.V., \& Tashian, R.I. (2019), Protection of ownership right in the court: the essence and particularities. Asia Life Science, 21(2), 1-19.

/30/ Verkhovna Rada of Ukraine. (2014), Law of Ukraine "On the Prevention of Corruption". Retrieved from https:/zakon.rada.gov.ua/laws/show/1700-18\#Text

/31/ Verkhovna Rada of Ukraine. (1984), Code of Ukraine on Administrative Offenses. Retrieved from

https://zakon.rada.gov.ua/laws/show/8073110\#Text

/32/ Verkhovna Rada of Ukraine. (2001), Criminal Code of Ukraine. Retrieved from https://zakon.rada.gov.ua/laws/show/2341$14 \#$ Text

133/ Cherniavskyi, S.S., Golovkin, B.N., Chornous, Y.M., Bodnar, V.Y., \& Zhuk, I.V. (2019), International cooperation in the field of fighting crime: directions, levels and forms of realization. Journal of Legal, Ethical and Regulatory Issues, 22(3), 1-11.

/34/ Melnyk, O. (2021), International experience in preventing and combating corruption as a vector of formation of national anti-corruption policy in Ukraine. Legal Scientific Electronic Journal, 2, 32-35.

/35/ Suprun, T. (2017), Foreign experience in preventing and combating corruption. International Legal Bulletin: Current Issues (Theory And Practice), 2, 199-204.

/36/ op. sit. in /10/

/37/ Pykhtin, M. (2012), International experience in combating corruption. In Anti-corruption: European experience and Ukrainian realities: abstracts of the international scientific-practical conference (Lviv, April 2012) (pp. 130-135). Lviv: Lviv State University of Internal Affairs.

/38/ Shvydkyi, J. (2020), Foreign experience in combating corruption and the possibility of its implementation in Ukraine. Discussion Issues of Application of Anti-Corruption Legislation, 1, 219227.

/39/ op. sit. in /11/

/40/ Vasylevych, V., Cherniei, V., Husariev, S., \& Cherniavskyi, S. (2016), Corruption-related crimes in Ukraine: trends and current issues. In Implementation of State Anti-Corruption Policy in International Dimension: Proceedings of the International Scientific and Practical Conference (Kyiv, December 2016) (pp. 25-28). Kyiv: National Academy of Internal Affairs Affairs.

/41/ Dudorov, O. (2017), About distinction of the crime provided by article 368 of the criminal code of Ukraine, and the misdemeanor provided by article 172 - 5 of the Code of Ukraine about 
Informatol. 55, 2022., 1-2

administrative offenses. Bulletin of LDUVS named after E.O. Didorenko, 2, 84-99.

/42/ Subbot, A., \& Demyanchuk, Y. (2017), Means of counteracting and preventing corruption in the context of legislative reform. Entrepreneurship, Economy and Law, 6, 113-117.
/43/ Reznik, O., Getmanets, O., Kovalchuk, A., Nastyuk, V., \& Andriichenko, N. (2020), Financial security of the state. Journal of Security and Sustainability Issues, 9(3), 843-852 